\title{
Dorota Werbińska
}

Akademia Pomorska, Stupsk

\section{POSTRZEGANIE PROCESU \\ UCZENIA SIĘ JĘZYKA \\ OBCEGO W PERSPEKTYWIE \\ UCZNIÓW DOROSEYCH \\ (BADANIE JAKOŚCIOWE \\ NAUCZYCIELI \\ KONSULTANTÓW)}

\begin{abstract}
The article aims at presenting a longitudinal two-year study on the perception of language learning from the perspective of five adult learners in their late 50s who are teacher consultants by profession and participants of an elementary course in English. The attention is focused on two aspects: 1) what general expectations they have with regard to the course (ie. language skills, knowledge, teacher, etc.) at the beginning of their learning process, 2) what they achieve or fail to achieve after two years of attending the course. The conclusions may provide some implications for language teachers of mature learners as well as future directions for researchers of this topic.
\end{abstract}

\section{Wprowadzenie}

Wśród ważnych różnic indywidualnych w procesie uczenia się języka obcego coraz większą rolę odgrywaja przekonania uczniów. W konsekwencji pojawiaja się badania dotyczące poglądów uczących się: uczniów zdolnych, imigrantów, przyszłych nauczycieli, uczniów szkół różnego szczebla itp. Badania postrzegania procesu uczenia się przez uczniów dorosłych to często introspekcje przeprowadzane na studentach różnych kierunków, do których autorzy artykułów glottodydaktycznych - zwykle pracownicy uczelni wyższych - mają łatwy dostęp, a w praktyce oznaczają badania osób we wczesnej dorosłości. Studia nad osobami dojrzałymi mają miejsce znacznie rzadziej, choć, zważywszy na fakt, że edukacja 
podnosi jakość życia ludzi, w ostatnich czasach wiele osób w wieku trzecim podejmuje naukę języka obcego. Jeszcze rzadziej pojawiają się badania dotyczące nauczania języków obcych, których obiektem są przedstawiciele konkretnych grup zawodowych, a jeśli takie występują, dotyczą one zwykle grup biznesowych, gdzie przedmiotem dociekań są różne aspekty nauczania języka biznesu. Niniejszy artykuł ma na celu próbę wypełnienia tej luki i skupienie uwagi na uczniach dojrzałych (w wieku powyżej 50 lat), byłych nauczycielach różnych przedmiotów, a obecnie pracownikach oświaty zatrudnionych na stanowiskach nauczycieli konsultantów oraz tym, co oni mają do powiedzenia na temat własnego procesu uczenia się języka obcego. Poglądy takiej grupy mogą przedstawiać wartość z kilku powodów. Po pierwsze, nauczyciele, a więc osoby nauczające innych, mają rozwój zawodowy wpisany w swoja profesję i można założyć, że podejmując się nauki języka obcego, będą grupą zmotywowaną, żądną wiedzy, potrafiącą odróżnić rzeczy ważne od mniej istotnych, a przez to, być może, wprowadzić nową jakość do procesu uczenia się języka ze swojego punktu widzenia. Po drugie, nauczyciele konsultanci, a więc osoby odznaczające się bardzo dużym doświadczeniem zawodowym ${ }^{1}$ i udzielający na co dzień porad metodycznych nauczycielom praktykom są grupą świadomą dydaktycznie, zaznajomioną z teoriami i procesami uczenia się, i z tego względu można oczekiwać, że potrafią wyróżnić ważne sygnały czy aspekty towarzyszące ich procesowi uczenia się języka obcego znacznie lepiej niż osoby z mniejszym doświadczeniem. Po trzecie, badanie przekonań osób po 50 roku życia stanowi wartość samą w sobie, bowiem, „kultura, w której dojrzałość nie jest ceniona, nie wie, skąd pochodzi i dlatego nie może mieć pojęcia, dokąd zmierza" (Eriksen, 2003: 160).

\section{Podstawy teoretyczne}

Teoria Uczenia się Dorosłych (Adult Learning Theory) oparta jest na czterech założeniach prekursora andragogiki Malcolma Knowles'a (1975) sprowadzających się do tego, że: 1) dorośli potrzebują celu uczenia się, 2) dorośli muszą uczyć się w nawiązaniu do własnych doświadczeń, 3) proces uczenia się dorosłych powinien przybierać formę rozwiązywania problemów, 4) dorośli uczą się najefektywniej, kiedy temat jest przez nich samych uważany za wartościowy. W praktyce oznacza to, że nauczanie dorosłych powinno być nakierowane na osiągnięcie celu, a cechy promowane w środowisku uczenia się języka obcego przez dorosłych to autonomiczność i samo-sterowność.

W literaturze glottodydaktycznej studia nad akwizycją języka obcego osób dorosłych koncentrowały się głównie na kwestii wieku, przyjmując perspektywę biologiczną (np. Singleton i Ryan, 2004) i kognitywna, rzadziej uwzględniając aspekty społeczne czy edukacyjne (Larsen-Freeman, 2001). Dopiero ostatnio w

1 Aby zostać nauczycielem konsultantem, wymagany jest staż pracy nauczyciela wynoszący minimum 10 lat 
nauczaniu dorosłych dostrzegamy ,zmieniające się znaczenia” (Malewski, 2010: 18) podkreślające wartość badań biograficznych o uczeniu się ludzi dorosłych (np. Shoaib and Dornyei, 2005; Bellingham, 2005) oraz zmianę indywidualnej tożsamości (np. Block, 2007). Te nowe wątki, a zwłaszcza transformacja własnej tożsamości wydają się obiecujące ze względu na niedobór badań skoncentrowanych na osobach „w kwiecie wieku”, jak również studiów odwołujących się do kontekstów społecznych. Studium opisywane poniżej próbuje wpisać się w ten nurt.

\section{Badanie}

Referowane tu badanie miało charakter podłużny i obejmowało dwa zasadnicze etapy. Pierwszy etap miał na celu określenie przekonań uczestników na początku procesu uczenia się języka obcego, zaś etap drugi, mający miejsce dwa lata później od momentu rozpoczęcia nauki, ukazanie korzyści z uczenia się języka w perspektywie uczestników badania.

\subsection{Kontekst}

Uczestnikami badania uczyniono 5 nauczycielek konsultantek pracujacych w ośrodku doskonalenia nauczycieli w dużym mieście powiatowym. Z wykształcenia osoby badane były absolwentkami biologii (2 osoby), filologii polskiej (2 osoby) oraz bibliotekoznawstwa (1 osoba) w wieku powyżej 50 lat. Tabela 1 podaje także kilka dodatkowych informacji o uprzednich doświadczeniach badanych, które mogą odgrywać rolę zachęcającą lub blokującą ich dalsze uczenie się. W chwili rozpoczęcia badania (etap I), uczestniczki od sześciu miesięcy uczęszczały na kurs początkujący języka angielskiego organizowany i odbywający się w ramach pracy w ośrodku i finansowany ze środków unijnych. Zajęcia odbywały się raz w tygodniu w systemie dwugodzinnym, choć wiele lekcji odwoływano ze względu na bieżące prace konsultantek. Jeszcze przed badaniem właściwym, autorka obejrzała 4 lekcje kursu, aby lepiej uchwycić klimat zajęć i trafniej przygotować ewentualne pytania w planowanej dyskusji. Zajęcia prowadził młody nauczyciel akademicki, mężczyzna, który sam ukończył Kolegium Językowe, a następnie studia magisterskie ze specjalizacją komunikacyjną.

\begin{tabular}{|l|l|c|}
\hline Uczestniczka & Przedmiot, dodatkowe informacje & Wiek \\
\hline Teresa $^{2}$ & $\begin{array}{l}\text { Emerytowana nauczycielka biologii, autorka podręcznika do } \\
\text { szkoły średniej, ze względu na wypromowanie licznych olimpij- } \\
\text { czyków uważana za najlepszego biologa w mieście i jednego z } \\
\text { wiodących wraju }\end{array}$ & 57 \\
\hline Iwona & $\begin{array}{l}\text { Nauczycielka biologii w gimnazjum, regularnie wyjeżdżająca z } \\
\text { mężem lekarzem na wycieczki zagraniczne była między innymi } \\
\text { w Australii, Indiach, Izraelu, Meksyku oraz w prawie wszystkich }\end{array}$ & 58 \\
\hline
\end{tabular}

${ }^{2}$ Imiona uczestniczek badania zostały zmienione 


\begin{tabular}{|l|l|c|}
\hline \multicolumn{2}{|l|}{ krajach Europy) } & 59 \\
\hline Maria & $\begin{array}{l}\text { Bibliotekarka, osoba schorowana, samotna, ale pogodna i ogólnie } \\
\text { lubiana }\end{array}$ & $\begin{array}{l}\text { Emerytowana nauczycielka języka polskiego, samotna, uważana } \\
\text { za jedna z najlepszych polonistek w mieście }\end{array}$ \\
\hline Barbara & $\begin{array}{l}\text { Polonistka, posiadająca dużą łatwość zjednywania do siebie ludzi } \\
\text { i wzbudzania ich zaufania, robiąca dobre wrażenie, imponująca } \\
\text { wiedzą i erudycją już przy pierwszym spotkaniu }\end{array}$ & 51 \\
\hline
\end{tabular}

Tabela 1: Uczestniczki badania.

\subsection{Pytania badawcze}

Obszarem referowanego tu badania uczyniono przemyślenia badanej grupy wiekowej na temat różnych aspektów uczenia się języka angielskiego, a w szczególności:

1. Kim są uczący się dorośli, jakie są ich oczekiwania względem nauczyciela i zdobywanej wiedzy/umiejętności?

2. Co zyskuja po dwóch latach uczęszczania na kurs? Czy zachodzą u nich przemiany pod względem językowym i/lub niejęzykowym?

Oczekiwano, że uzyskanie odpowiedzi na postawione wyżej pytania może przyczynić się do lepszego zrozumienia, w jaki sposób proces uczenia się języka obcego jest postrzegany przez badanych pracowników oświaty w wieku dojrzałym, co stanowi treść ich przemyśleń, jak również jakie są efekty rozpoczynania nauki języka obcego po 50ce. Uznano także, że eksploracja przekonań respondentek pozwoli być może wychwycić nowe akcenty w myśleniu o edukacji dorosłych i sporządzić swoistą mapę priorytetów istotną dla każdego, kto podejmuje się nauczania tej grupy wiekowej.

\subsection{Metodologia}

Do niedawna, za najbardziej popularny instrument badawczy stosowany do badania przekonań uczących się uważano kwestionariusz, a wśród nich znany inwentarz Horwitz'a (1985), BALLI. Jednak w ostatnim czasie podkreśla się związek przekonań z kontekstem uczenia się, co powoduje częste korzystanie z metod jakościowych: etnograficznych (np. Ho, 2007), narracyjnych (Kalaja et al., 2008) i opartych na metaforach (Kramsch, 2003). Cechą podejścia kontekstualnego jest nie tylko różnorodny sposób umocowań teoretycznych badań (nawiązania do nurtu neo-Wygockiego (np. Alanen, 2006, Lantolf, 2000), odwołania do ideologii Dewey’a (np. Barcelos, 2006) czy Bakhtina (np. Dufva, 2006, Hosenfeld, 2006), ale również różnorodność metod stosowanych do zbierania danych, wśród których można wyróżnić studia przypadków, obserwacje zachowań, dyskusje nieformalne, dzienniki czy analizy dyskursów. Podejście kontekstualne zachęca do wykorzystania perspektywy ekologicznej, zgodnie z którą „,cokolwiek dzieje się w badanym kontekście staje się częścią badania i nieuchronnie prowadzi do perspek- 
tywy krytycznej” (Bernat i Gvozdenko 2005). Zastosowanie wywiadu, obserwacji czy terenowych notatek (field notes) może ukazać, w jaki sposób niektóre przekonania uczących się są konstruowane w obecności i przy współudziale innych osób nauczyciela, innych uczniów, badacza (affordances) oraz jak się wynurzają (emergence). Podejście ekologiczne respektuje codzienność, a więc sytuacyjność uczenia się (situated learning) i zakorzenienie we właściwych dla siebie środowiskach społecznych. Perspektywę ekologiczną zastosowano w etapie I badania.

\subsubsection{Wprowadzenie do Etapu I}

Etap I badania, mający na celu pozyskanie danych dotyczących przekonań uczestników na początku kursu polegał na nagraniu rozmowy uczestniczek badania na temat swoich przemyśleń odnośnie nauki języka obcego. Dyskusja, która została nieświadomie sprowokowana przez autorkę, odbywała się w mieszkaniu prywatnym autorki w lutym 2009, przy okazji spotkania towarzyskiego ${ }^{3}$. Autorka założyła, że interesujące ja przemyślenia, spontanicznie wyrażane przez rozmówczynie, warto zarejestrować na dyktafonie. W chwili odbywania rozmowy, uczestniczki nie były świadome, że są nagrywane, choć po zakończeniu rozmowy na temat swojego uczenia się języka obcego, wyraziły zgodę na potencjalne wykorzystanie nagrania do celów badawczych, kiedykolwiek autorka uzna to za stosowne. Warto dodać, że zarówno badane, jak i autorka sa osobami zaprzyjaźnionymi, co z pewnością sprzyja większej otwartości i szczerości wypowiedzi uczestniczek, jak również eliminuje potencjalny ,efekt interlokutora". Ponieważ naszym zasadniczym zadaniem jest skupienie uwagi na przemyśleniach nauczycieli konsultantów, w opracowaniu podane są ich ,,autentyczne opinie" oraz faktycznie użyte słowa. Założono także, że poglądy respondentek we wczesnym stadium nauki staną się cennym materiałem przy analizie oraz porównywaniu danych uzyskanych w etapie II, kiedy będzie można wyraźniej wskazać tendencje występujące wśród tej grupy wiekowej.

\subsubsection{Wyniki i omówienie:}

Dyskusja autorki z 5 konsultantkami, uczestniczkami kursu języka angielskiego, umożliwiła dostrzeżenie następujących obszarów istotnych dla osób badanych.

\section{Wpływ działań dawnego nauczyciela}

Już Lortie (1975) zaznaczył, że na działania nauczycieli duży wpływ wywieraja doświadczenia z czasów, kiedy oni sami byli uczniami. Podążając tym tropem, można również zauważyć, że w procesie uczenia się nowego języka obcego od-

\footnotetext{
3 Autorka planowała przeprowadzenie dyskusji na temat wrażeń konsultantek z kursu uczenia się języka angielskiego, lecz nie wyznaczyła terminu, kiedy dokładnie dyskusja miała się odbyć.
} 
zywają się wszystkie przeżycia związane z uczeniem się innych języków, wśród których doniosła role odgrywają dawni nauczyciele. Wpływ byłych nauczycieli języków obcych najczęściej przejawia się w dwóch aspektach: konfrontowaniu poprzednich nauczycieli z obecnymi oraz zawdzięczaniu bądź przypisywaniu nauczycielom z przeszłości cech posiadanych i uważanych za istotne przez uczących się w procesie nabywania języka obcego. W opisywanym tu badaniu ważną cechą dla Joanny okazuje się elastyczność nauczyciela. Jej nauczycielka języka rosyjskiego z czasów licealnych potrafiła oddzielić rzeczy ważne od nieważnych (wówczas kwestie polityczne od językowych), nawiązywać do zainteresowań uczniów (nauczanie języka poprzez literaturę), zaś inny nauczyciel posiadał umiejętność dopasowywania się do uczniów i dzięki temu, jak sama podała, „wyzwalania” u nich uczenia się. Dzięki poprzednim doświadczeniom językowym skoncentrowanym na rozwijaniu kompetencji komunikacyjnej przez rodowitą Niemkę podczas nauki języka zachodniego w liceum 35 lat temu, Barbara nie ma dzisiaj lęku przed komunikowaniem się w języku obcym, chętnie nawiązuje rozmowę, uruchamiając dostępne jej słowa umożliwiające skuteczne porozumiewanie się (,swoboda językowa znaczna, odwaga komunikacyjna wyrobiona, ktokolwiek zacznie mówić po niemiecku w sklepie, na ulicy, ja już staram się rozumieć i moge mówić”). Z kolei, swojego nauczyciela rosyjskiego ze studiów wspomina jako ,świetnego pana, który pytał, o jakich tekstach chciałyby rozmawiać”. Wtedy, jak wspomina ,gramatyka szła obok, a my czytałyśmy artykuły prasowe czy literackie i zawsze miałam piątkę". Podobnie Teresa nawiązuje do wcześniejszych doświadczeń, uważając że na kursie dla konsultantów jedynie powtarza informacje, ponieważ wszystkie je poznała wcześniej w trakcie intensywnego prywatnego kursu angielskiego (,4 lata temu przeszłam bardzo intensywny kurs dla początkujących i dzięki tamtej nauczycielce w krótszym czasie nauczyłam się więcej”). Wyraźnie zatem widać, że poprzednie doświadczenia osób dojrzałych związane z procesem uczenia się języka obcego rzutują na ich oczekiwania i postępowanie podczas nowego kursu, a prowadzący go nauczyciel jest nieustannie porównywany z poprzednimi nauczycielami, czy to pod względem posiadanych cech, sposobu prowadzenia zajęć, czy też w kontekście wyznawanych priorytetów w nauczaniu języka obcego.

\section{Uporządkowanie}

Badane konsultantki wyraźnie dostrzegają wartość porządkowania wiadomości. Być może, w obliczu nowego kodu językowego i gąszczu informacji, szukanie regularności w języku staje się dla nich swoistym mechanizmem obronnym, a odróżnianie rzeczy istotnych od mniej ważnych jedną z podstawowych umiejętności warunkujących skuteczne uczenie się. Prawie wszystkie zgodnie podawały, że nie korzystają z ,ciekawostek” podawanych przez nauczyciela, sprowadzających się do demonstrowania za jednym razem kilku znaczeń danego słowa czy podawania różnych słów w wersji brytyjskiej i amerykańskiej. Dzielenie się wiedzą jest wpisane w zawód nauczyciela i prawdopodobnie każdy pedagog posiada 
chęć podania innym tego, co wie, ale wprowadzanie zbyt wielu szczegółów może powodować wyłączanie się (Barbara: „Jeżeli pan w ferworze przechodzi z piętra na piętro, z jednego zakresu słowa na drugi, to ja się wyłączam”, a nawet „Ciekawostki nie są ciekawostkami, ale sytuacjami - może nie stresogennymi, ale powoduja, że to, co wypracowałam do tego momentu, gdzieś tam się zatraca"). Oznacza to, że podawanie przez nauczyciela zbyt wielu informacji w krótkim przedziale czasu może działać na starszych uczestników deprymująco, a powroty, regularności, nawet schematy odciążaja pamięć mechaniczną dorosłych uczestników kursu. Rozumując zasadę czy poznając kilka słów, raczej niż kilkanaście, czują się bezpieczniej.

W kontekście „uporządkowania”, konsultantki poruszają także temat odbitek ksero, tak często używanych przez nauczycieli języków obcych. Oto wypowiedź Teresy na ten temat: „[Kiedyś] była książka, teraz kserówki. Nawet chciałam coś uporządkować i zamknęłam zeszyt. Ja uczyłam się wcześniej tylko 3 miesiące, ale bardzo intensywnie, 3 razy w tygodniu, opuściłam tylko jeden tydzień, ale wtedy wzięłam zeszyt do pociagu i uczyłam się. Tam był porządek. A tutaj chciałam tak zrobić, ale w notatkach bałagan przez te wszystkie kserówki z ćwiczeniami". Takie stwierdzenia mogą okazać się cenne dla pracy nauczyciela, znacznie młodszego od swoich uczennic i prawdopodobnie nie zdającego sobie sprawy z innych nawyków uczenia się. Badane panie wyraźnie wskazują na potrzebę posiadania uporządkowanych notatek, będących odzwierciedleniem zajęć, ponieważ, jak twierdzi Barbara: „To są moje notatki, które mimo tego zamieszania, stanowią oparcie pozwalające mi brać aktywny udział w lekcji”.

Pomimo wyraźnej niezgody na brak ładu na lekcji, można założyć, że nauczyciel nie zdaje sobie sprawy z faktu, że jego uczennicom przeszkadza podawanie przez niego zbyt wielu, z ich punktu widzenia niepotrzebnych, informacji w ciagu jednej jednostki lekcyjnej, gdyż badane nie komunikuja tego otwarcie. $\mathrm{Na}$ tym etapie uczenia się języka obcego, jest im prawdopodobnie trudno zaakceptować brak władzy ze strony nauczyciela, do którego przywykły w przeszłości, a łatwo przyjąć rolę ucznia, dobrze znaną z przeszłości. Być może daje tu o sobie znać tradycyjne pojmowanie wiedzy w sensie obiektywnym, zaś umysły uczących się jako puste.

\section{Emocje}

Emocje zawsze towarzyszyły procesowi uczenia się języka obcego i wiele opracowań glottodydaktycznych poświęcono kwestiom afektywnym. Ponieważ grupa badanych uczestniczek kursu jest zespołem zgranym, można przyjąć, że nie występuja w trakcie nauki inne negatywne zjawiska opisywane w literaturze przedmiotu, w rodzaju rywalizowania uczniów ze sobą (Bailey, 1995; Block, 2007), stresu czy poczucia lęku (Oxford, 1999). Niemniej, z dyskusji wynika, że Joanna nie jest całkowicie rozluźniona, gdyż w swojej wypowiedzi wskazuje na to, że fakt uprzedniej znajomości nauczyciela nie jest bez znaczenia dla osoby dojrzałej („Chciałabym móc się odblokować. Ważne są osoby, przed którymi 
czuję się swobodnie - chodziłam w zeszłym roku na 3-miesieczny kurs angielskiego dla nauczycieli organizowany ze środków EFZu. Nie znałam pana, on mnie nie znał. Tu znam pana skądinąd i cała moja rodzina wie, jak się uczę"). O blokadzie mówi także Maria, choć w odniesieniu do sytuacji komunikacyjnej poza klasą. Twierdzi, że „W momencie, gdy jest koło mnie ktoś, kto lepiej zna angielski, tworzy się blokada. Ja nadal rozumiem, ale wyartykułowanie jest ponad moje siły". Zatem inne osoby mogą okazać się ważnym czynnikiem utrudniającym proces „odblokowania się”, warunkujący skuteczne uczenie się. Z tego powinien zdawać sobie sprawę nauczyciel, który sam może okazać się czynnikiem blokującym uczniów. Z kolei Teresa złości się na wszelkie straty czasu lekcji, twierdząc, że „Dużo czasu mija zanim wiadomo, kto pierwszy ma mówić. Sekundy umykają bardzo mnie to boli - każda strata czasu". Uczucia złości z powodu marnowania czasu moga mieć często miejsce w przypadku dojrzałych osób, które są ambitne, zmotywowane lub bardziej zaawansowane pod względem językowym niż inne osoby w grupie. Dla tych pierwszych każda dygresja niezwiązana z tematem zajęć, każde późniejsze rozpoczęcie czy przeciągnięcie przerwy stanowi utratę cennego czasu.

\section{Motywacja}

Motywacja do uczenia się języka angielskiego jest obecna w omawianym tu I etapie badań, ponieważ wszystkie badane uczestniczki uczęszczają na zajęcia, są zainteresowane opanowaniem języka angielskiego i, choć moga przejawiać różne motywy, generalnie cieszą się z faktu, że taki kurs oferowany jest przez pracodawcę (Teresa: „Angielskiego chcę się nauczyć. Jak coś jest za darmo, zawsze korzystam”, Maria: „Mam ogromne pragnienie umiejętności tego języka”, czy Iwona: „Ja na te zajęcia chodzę z przyjemnością. Cieszę się jak dziecko, że umiem trochę więcej. Jestem w samolocie, pan mnie pyta, a ja potrafię odpowiedzieć, pójdę do sklepu, pytam, ile to kosztuje...”). W przypadku konsultantek dominuje motywacja o orientacji instrumentalnej, dotycząca wyjazdów turystycznych (Iwona: „Zaczęłam się uczyć z powodu częstych wyjazdów za granicę, gdyż czułam się potwornie źle, gdy byłam skazana na mojego męża”), komunikowania się z innymi (Maria: „Język dla mnie to komunikacja, za granica czy nawet tutaj. Żebym nie musiała polegać na kimś obok, wstydzić się”), poprawnego odczytywania i wymawiania angielskich słów (Joanna: „Mi angielski jest bardziej potrzebny do czytania tekstów niż porozumiewania się. Wstyd mi nazywać coś po polsku, kiedy powinno się użyć angielskiego”), bez jednego wyraźnego motywu, choć z otwarciem na to, co nowe (Teresa: „Ja chętnie chodzę wszędzie, gdzie ktoś mi powie coś nowego"). Już ta mała 5-osobowa grupa ukazuje, że motywy uczenia się nie są jednakowe. Kurs języka angielskiego przygotowujący do wakacyjnych podróży zagranicznych czy stawiający sobie za cel nauczenie konwersacji musi różnić się od kursu nakierowanego na czytanie i wymawianie angielskich słów. Różne jest również inwestowanie we własne uczenie się języka ze strony uczących się (Norton 2010). Dlatego pogodzenie 
interesów uczestników nie jest łatwym zadaniem dla nauczyciela, który po pierwsze, musi być świadomy występujących motywów uczenia się, a po drugie, próbować wykorzystać tę wiedzę o uczniach w programie swoich zajęć.

\section{Cechy procesu uczenia się}

Z przeprowadzonej dyskusji z konsultantkami, doświadczonymi nauczycielkami innych przedmiotów można także wychwycić istotne dla nich cechy dotyczące nauczania i oceniania języka obcego. Odnośnie nauczania, pojawiają się głosy konsultantek narzekające na problemy ze sprawnością rozumienia ze słuchu. Joanna twierdzi, że należy do tej grupy ludzi, którzy nie słuchali muzyki z tekstami angielskimi, „tak więc mój słuch, pomijając wiek, jest taki, ze mogę powiedzieć, że jestem głucha na ten język”. Iwona dodaje, że „Zawsze miałam kłopoty z rozumieniem ze słuchu. Gdy słucham filmów, rozumienie ułatwiaja napisy. Ale wielu rzeczy nie słyszę". Sprawność słuchu ulega pogorszeniu wraz z wiekiem, a zważywszy na fakt, że rozumienie dotyczy nowego kodu, wyzwanie dla osoby dojrzałej staje się jeszcze większe. Obawa przed niezrozumieniem, niepewność siebie w nowej roli użytkownika nieznanego języka mogą skutecznie powstrzymywać proces percepcji dźwiękowej i dekodowania obcobrzmiących słów. Dlatego nauczyciel pracujący z uczniami powyżej 50 lat nie może być obojętny na rozwijanie tej sprawności językowej. Podwyższanie świadomości uczniów względem sprawności słuchania ze zrozumieniem (np. omówienie różnych rodzajów słuchania i strategii w nich stosowanych), dostarczanie poczucia sukcesu (np. chwalenie), czy stosowanie technik obnizających bariery afektywne uczniów (np. wykorzystanie pracy w parach czy grupie) może przyczynić się do zmniejszenia trudności uczniów z rozumieniem mowy obcojęzycznej.

Uczestniczki badania są nauczycielkami, a więc ze względu na wykonywaną profesję z założenia otwartymi na treści nowe, często związane z kultura. Dla Barbary uczenie się języka jest spotkaniem z kulturą, z drugim człowiekiem „Dla każdego inny odcinek w kulturze jest ważny, dla mnie sa to muzea w Londynie, a drugi człowiek to ludzie, z którymi miałam kontakt. Pan, mówiąc o miejscach, w których był, też mnie otwiera na język. Nie jest złe, jeśli pojawiaja się informacje kulturowe, byleby nie w nadmiernej ilości". Takie opinie oznaczaja, że rozwijanie kompetencji kulturowej może być atutem zajęć z języka obcego skierowanych do pracowników oświaty. Należy jednak wprowadzać treści kulturowe $z$ umiarem, aby przesyt wiadomości kulturowych nie spowodował utraty poczucia kierunku, a kurs języka nie zamienił się w kurs o kulturze kraju.

Interesujące przemyślenia dotyczą sprawdzania wiedzy uczniów dorosłych. Z jednej strony uczestniczki dopominają się systematycznych powtórzeń, kiedy mówią, tak jak Teresa, że „Jest za mało klasówek. Mnie tego brakuje. Chcę wiedzieć, co umiem, a co powinnam ćwiczyć. Bo takie krążenie wokół to szkoda czasu. Ja mówię, jak ja uczę i chciałabym, aby też tak było”, także z tego powodu, że sprawdzian działa na nie motywująco (Iwona: „Zapowiedź kartkówki spowodowała przypływ motywacji - uczyłyśmy się z Maria, zajrzałam w domu, jakbym 
była niedojrzała. Doszłam do wniosku, że potrzebuję klasówki, żebym się zmusiła do nauki”). Z drugiej strony, krytycznie wypowiadają się o sprawdzianach dołączonych do kursu, przygotowanych przez wydawnictwa, ze względu na nadużywanie w nich schematów (Maria: „Spodziewałyśmy się tłumaczeń, tworzenia pytań, zdań, które trzeba przetworzyć, a tu tylko schematy: dodaj „s”, zamień na „,'”"'). Ciekawy punkt widzenia zaprezentowała Barbara zwracając uwage na istotność podsumowań i powtórek w formie użytkowej: „Powinno się przenieść to na moje doświadczenie, moje miasto, mój wyjazd, moją rodzinę, nawet w formie pracy domowej. To nie może być sprawdzian taki formalny, ale samodzielnie coś zebrać i napisać, np. kim jestem, kim nie jestem, co lubię, czego nie robię. To są ćwiczenia do zrobienia, które porządkowałyby jakoś”. Tak więc widzimy, że ponownie podkreślana jest kwestia porządkowania materiału, ale w formie użytkowej, ,prawdziwej” i spersonalizowanej dla uczestniczek kursu.

\subsubsection{Wnioski z Etapu I}

Powyższa dyskusja generuje wnioski odnoszące się do przekonań kursantek uzyskanych w wyniku badania na etapie I. Jednocześnie mogą one stanowić kierunek, o jaką wiedzę należy zabiegać w procesie nauczania języków obcych uczniów dorosłych, przedstawicieli zawodu nauczycielskiego:

- Treści muszą być postrzegane przez samych uczących się za ważne (np. nauczycielki interesujące się literaturą chętnie uczą się języka poprzez teksty literackie).

- Wstyd z powodu własnej niekompetencji językowej powoduje ważność uczenia się w sytuacjach bezpiecznych, nawet in cognito, gdzie dorośli moga pozwolić sobie na popełnienie błędu.

- Porządkowanie informacji, podsumowania daja uczącym się języka poczucie bezpieczeństwa. Należy przy tym pamiętać, że powtarzanie bez końca może u niektórych uczących się powodować poczucie straty czasu.

- Logiczne i uporządkowane notatki stanowią oparcie dla uczniów dorosłych.

- Wiele osób w wieku starszym ma problemy z blokadą utrudniającą mówienie oraz ze sprawnością rozumienia ze słuchu.

- Duże zaufanie do nauczyciela powoduje pasywne przyjmowanie informacji, godzenie się na ich ilość, choć prywatnie dorośli mogą uważać, że informacji jest za dużo.

- Wprowadzanie zbyt dużej ilości informacji na raz powoduje chaos i niechęć do uczenia się języka.

- Sprawdziany wiadomości nie powinny być szablonowe, lecz uwzględniać subiektywne treści, ważne dla uczących się - występuje opór wobec schematycznych testów dla wszystkich, odległych od świata uczących się, polegających na mechanicznej zastępowalności struktur, 
- Niektóre osoby oczekuja, że nauczyciel będzie uczył w taki sposób, jak one same nauczają innych (np. częste klasówki, dostosowywanie treści do zainteresowań).

\subsubsection{Etap II}

Etap II, mający miejsce w styczniu i lutym 2011, polegał na nagraniu wywiadów z tymi samymi respondentkami indywidualnie, po dwóch latach ich pracy nad językiem. Celem tej części badania było określenie, czy i w jakim stopniu zaszła zmiana w mniemaniu konsultantek (samoocena respondentek) względem ich umiejętności językowych. Tym razem zastosowaną metodą badawczą był wywiad częściowo ustrukturyzowany (cf. Wilczyńska i Michońska-Stadnik 2010: 159), w którym badacz nadał kierunek omawianym tematom, lecz badane mogły wypowiedzieć się na nie, w zależności od własnych możliwości i chęci podzielenia się swoimi przemyśleniami.

Poniżej przedstawiamy informacje o uczestniczkach dwa lata później oraz fragmenty wywiadów odnoszacych się do tego, czy i jak nauka języka obcego zmieniła je.

\subsubsection{Wyniki i omówienie}

Wyniki z etapu II umożliwiły wyróżnienie 5 obszarów charakterystycznych dla sytuacji każdej z badanych osób. Cechy te okazały się odpowiedzialne za zmianę lub jej brak u poszczególnych uczących się.

\section{Joanna: obciążenia psychiczne są przeszkodą}

Niedługo po przeprowadzeniu pierwszego etapu badania, zrezygnowała z uczęszczania na kurs. Początkowo uczestniczyła w nich jako „,wolny słuchacz”, aby po kilku tygodniach zarzucić kurs całkowicie.

Bardzo dużo zależy od tego z kim mamy lekcje, kto jest nadawca, a kto adresatem. To powoduje, że czasem doznajemy uczucia lęku, czasem wstydu. U mnie jest bardzo duży krytycyzm wobec siebie, oczekiwania formy doskonałej, obawa przed kompromitacja, ośmieszeniem się przed samą sobą. Dotyczy to wszystkiego, również mojej specjalności - języka polskiego Są to obciążenia psychiczne, można rzec, że rozwaga czyni nas tchórzami. Jeżeli wiem, że to jest dobre, ja płynę. Ale musze mieć pewność, że zrobiłam to dobrze. Wszelkie pomyłki - o nie tak łatwo przy uczeniu się języka - powodują zatrzymywanie myśli, błądzenie, zacinanie. Pewnie są konsekwencją lęku albo ambicji. Kiedy mam przed sobą tekst angielski, daję sobie radę. Kiedy występuje kontekst kulturowy (np. tekst o Szekspirze), kojarzenia u mnie są automatyczne.

Można powiedzieć, że Joanna poniosła fiasko, gdyż nie poradziła sobie z własnymi obciążeniami psychicznymi. Odnosząc sukcesy w przeszłości, być może 
nie założyła tego, że proces uczenia się języka obcego obfituje w lęki, radzenie sobie z własnymi ułomnościami, czasami kompleksami. Obawa przed kompromitacja, uczucie wstydu, zwłaszcza przed osobą młodszą, poniekąd znajomym nauczycielem prowadzącym zajęcia, wiązało się ze zbyt dużym ciężarem, którego nie mogła bądź nie chciała znosić.

\section{Iwona: nowe wymiary, nowe tożsamości}

Nawet po dwóch latach, sprawia wrażenie najbardziej przejmującej się uczestniczki zajęć. Zawsze odrabia wszystkie prace domowe, nalega na odpracowywanie nieodbytych zajęć, dopytuje inne osoby o wyjaśnienia trudnych dla niej zagadnień przed lekcją angielskiego.

Po co ja się uczę angielskiego? Żeby rozumieć to, co do mnie mówią, porozumieć się. Mam barierę w mówieniu w angielskim - na zajęciach i za granica. Nie wiem dlaczego, ale wydaje mi się, że boję się niewłaściwej wymowy, gdy mówię, nie robię tego swobodnie - jest to dyskomfort, który przeżywam. Zdarzyło się, że zrezygnowałam ze spędzenia atrakcyjnego wieczoru, gdyż wiedziałam, że będą tam osoby nalegające na rozmawianie po angielsku. Coraz częściej myślę, jak czują się na lekcjach dzieci, kiedy wiedza, że są nieprzygotowane. Własne reakcje i emocje, których doznaję teraz, przekładają się na moja pracę. Rozumiem też dzieci, które coś kombinują, nie przychodzą na lekcję - zauważam, że sama podobnie się zachowuję, np. cieszę się, gdy nie ma angielskiego - jest to dziwne.

Poświęcam mniej czasu na angielski niż kiedyś, choć trochę wysiłku mnie to kosztuje, nie powiem, a postępy są nieadekwatne do nakładu pracy. Jest to przede wszystkim moja wina, ale nie tylko. Coraz więcej widzę, że to metodyka pracy, że uczę się nie tego, co bym chciała. Bo jak pan kazał napisać biznes plan, wydawało mi się to absurdalne. Po co mi takie rzeczy? I znowu myślę o uczniach, jak często uczą się rzeczy nieciekawych, które nigdy im się nie przydadza, ci, którzy nie mają chęci i nie lubią biologii. Poprzez angielski posadziłam znowu siebie w ławce.

$\mathrm{Na}$ zajęciach staram się zapisywać niektóre rzeczy, potrzebuję tego - ułomność wieku? Jak pan wprowadza coś nowego, ja potrzebuję ciszy, aby to przetrawić wewnętrznie, usystematyzować, ułożyć sobie, tak dla siebie - wtedy jestem bezpieczniejsza, bezpieczniej poruszam się.

W domu jest już mniej stresująco niż wtedy, gdy rozmawiałaś z nami dwa lata temu. Mąż chodzi na angielski dwa razy w tygodniu i zna lepiej niż ja. Ostatnio pokazałam mu zwroty, które pan dał nam do przetłumaczenia, bo byłam ciekawa, czy coś się zmieniło, jakie są moje relacje z nim, jeśli chodzi o angielski. On ma dużo większy zasób słów, ale też miał wiele wattpliwości. Teraz go słyszę i nawet poprawiam.

Co zyskałam dzięki lekcjom angielskiego? Potrafię porozumieć się w hotelu, zapytać o drogę, poradzić sobie w sklepie. Najwięcej dało mi to samej, że coś mogę. Uważam, że komunikowanie się po angielsku to podstawowa umiejętność, wymóg czasu. Wcześniej czułam się taka gorsza, taka zahukana, z biednego kraju, niedzisiejsza. Udowodniłam sobie coś, to, że ja też mogę się nauczyć. Dlaczego nie mogę w tym wieku? Może nauczę się mniej, ale się nauczę. Sama siebie dowartościuję w ten sposób. Wyznaczam sobie małe cele, które osiagam. Traktuję tę naukę jako ćwiczenie umysłu też, konieczne jest ćwiczenie umysłu. 
Wypowiedź Iwony jest ciekawa z wielu względów. Najważniejsze jest to, że słychać w niej echa wyraźnych zmian dotyczących jej własnej tożsamości. Powątpiewała w możliwość nauczenia się języka w stopniu komunikacyjnym po 50ce, lecz udowodniła sobie, że można to osiągnać. Dowartościowała się w ten sposób przed samą sobą i swoim mężem, który dokuczał jej z powodu nieznajomości języka, a w chwili obecnej sama niekiedy go poprawia. Zyskała także cenną cechę dobrego nauczyciela, jaką jest empatia, gdyż potrafi wczuć się w rolę nieprzygotowanego czy niezainteresowanego tematem ucznia. To wszystko sprawiło, że potrafi zwerbalizować swoje potrzeby (powiedziała, że pisanie planu biznesowego jest dla niej nieużyteczne i chciałaby na lekcji uczestniczyć w przydatnych dla niej aktywnościach), zauważyć braki w warsztacie metodycznym nauczyciela, dokonać refleksji nad własnymi strategiami uczenia się. Dzięki nauce języka angielskiego Iwona sama dostrzegła ważne dla niej samej kwestie, a zdobycie tej nowej świadomości przyczyniło się do wygenerowania jej nowych tożsamości lingwistycznych (od zakompleksionej uczennicy do dowartościowanej kobiety), pociagających ze sobą nowe tożsamości nauczyciela (od nieczułego do empatycznego), jak również nowe tożsamości ucznia (od pasywnego i zdanego na nauczyciela do bardziej autonomicznego, myślącego o swoich indywidualnych potrzebach językowych). Można powiedzieć, że nauka języka angielskiego wzbogaciła Iwonę wewnętrznie, dostarczając na równi z korzyściami językowymi, pozytywnych efektów niejęzykowych.

\section{Barbara: potrzeba to możliwość (musieć znaczy potrafić)}

Bardzo nieregularnie uczęszcza na zajęcia, co często jest spowodowane nawałem pracy w ośrodku4. Pomimo niewielkiej znajomości języka, chętnie bierze udział w służbowych wyjazdach zagranicznych, nie stroni od kontaktów z cudzoziemcami, a nawet zabiera głos w dyskusji, choć wówczas prosi o przetłumaczenie. Opowiedziała o ważnym, z jej punktu widzenia, zdarzeniu, które obrazuje, co oznacza, że potrzeba jest tożsama z możliwością.

Dwa dni temu miała miejsce niecodzienna sytuacja. Do szkoły, w której mam także lekcje przyjechały dwie młode Francuzki w ramach wolontariatu. Przyszły do mnie na lekcje, a ja się z nimi po angielsku przywitałam, spytałam skąd pochodza, czy maja jakiś program pobytu w Polsce. Dzieci były zdumione: „To pani potrafi?”. Prawdopodobnie nie mają takich doświadczeń w domu, a jedna $z$ dziewczynek opowiadała, że za granicą ona pełniła rolę przewodnika dla swoich rodziców. Później dziewczyny prezentowały Francję, Paryż, swoją miejscowość. Ja sporo rzeczy rozumiałam i po większej części pełniłam rolę tłumacza, na pewno pewne rzeczy dopowiadając na bazie tego, co generalnie wiem o Francji. Ale mój angielski był na tyle komunikatywny, że powiedziałam, o której kończymy zajęcia, odczytywałam ich polecenia, typu przeczytaj, usiądź - mogłam kierować ruchem w klasie. Czułam rozbawienie, zaś na następnej lekcji, kiedy

\footnotetext{
${ }^{4}$ Jako jedyna z respondentek, Barbara pracuje w ośrodku na cały etat.
} 
uczniowie wypełniali ankiety, a sporo młodsza ode mnie koleżanka uciekła na koniec klasy, aby nie mieć kontaktu z Francuzkami, byłam jeszcze odważniejsza. Rozbawienie z powodu tego, że się nie mylimy, że nawiązałyśmy jakiś kontakt. Rozumiem znacznie więcej niż potrafię wyrazić. Było to bardzo miłe uczucie moc się przywitać, pożegnać, życzyć dobrego dnia, móc porozumieć się, choćby na takim elementarnym poziomie.

Korzyści z kursu angielskiego? Uczucie, że mogę się nauczyć, że nie jest to umiejętność, której nie jestem w stanie posiąść. Myślałam, że jest to nie do ogarnięcia, że nie mam zdolności językowej. Próbowałam śledzić rozwój językowy mojego syna, ale wtedy odpuściłam sobie kontakt z językiem. Może na tle grupy nie prezentuję się najlepiej, ale nie jest beznadziejnie. Myślę, że nigdy nie wiemy, co potrafimy, dopóki tego nie sprawdzimy. Sytuacja z Francuzkami pokazała, że ślad lekcji, kontaktów zagranicznych pozostaje. Już wiem, że gdybym znalazła się w ekstremalnej sytuacji, podjęła pracę i musiała zacząć mówić, nie miałabym blokady. To oswojenie, zbudowanie myślenia, że dam radę jest bardzo cenne. Okoliczności pokazują że nie próbujemy się zmierzyć do końca z językiem - trochę to sprawa lenistwa, trochę braku motywacji, ale kiedy wyjazd za granicę się zbliża, myślenie o języku pojawia się.

Podobnie jak w przypadku Iwony, udział w kursie języka angielskiego pomógł Barbarze udowodnić sobie, że w sytuacji, kiedy osoba jest zdana sama na siebie, uaktywniają się zasoby umożliwiające skuteczne porozumiewanie się czy, jak twierdzą Lantolf i Pavlenko (2001: 141-158), kontekst staje się źródłem rozwoju nowego języka, a nie jedynie tłem dla rozwoju językowego ucznia. Takie stanowisko można uznać za optymistyczne, ze względu na to, że podkreślany jest w nim sukces językowy. Z drugiej strony, może okazać się zwodnicze, gdyż może sprzyjać dorywczości i niesystematyczności. Niewątpliwie jednak wzbogaca ucznia o nowy wymiar, jak powiedziała Barbara, o „oswojenie i zbudowanie myślenia, że 'dam radę"”.

\section{Maria: upewnianie się}

Nadal uczęszcza na kurs, w miarę regularnie. Chyba jako jedyna respondentka, Maria bardzo wzbraniała się przed rozmowę. Wywiad z nią był bardzo krótki, można rzec wyproszony przez autorkę, a poniższe fragmenty zostały spisane ${ }^{5}$.

Korzyści z angielskiego po dwóch latach? Więcej rozumiem, np. jak czytam maile, jak ktoś coś mówi, choć Anglików wolę nie słuchać. Trudno powiedzieć, czasem próbuje oglądać wiadomości. Jak dzwoniła córka ciotki z USA, która niewiele mówi po polsku, próbowałam coś powiedzieć. Na pewno jest to niewiele, ale więcej niż rok czy dwa lata temu.

Choć, jak zaznaczono wyżej, stosunek Marii do wywiadu był dość sceptyczny, od czasu jego przeprowadzenia regularnie chwali się autorce, jak dużo zrozumia-

${ }^{5}$ Maria nie wyraziła zgody na nagrywanie, nie podając żadnej przyczyny. 
ła ze służbowego e-maila, a czasem prosi o sprawdzenie, czy przetłumaczyła informację elektroniczną poprawnie.

\section{Teresa: emancypacja}

Najszybciej ucząca się i najambitniejsza uczestniczka zajęć. Często pomaga pozostałym osobom, zwłaszcza przy odrabianiu prac domowych. Nie ma barier przed mówieniem i twierdzi, że bardzo chce się nauczyć języka angielskiego. Oto co ma do powiedzenia na temat kursu:

Początkowo wydawało mi się, że to dobrze, że jest kurs, że w czasie pracy i za darmo. Ale po tych dwóch latach, doszłam do wniosku, że się cofam w rozwoju, nic się nie nauczyłam, a zapominam. Ostatnio prosiły mnie koleżanki, żeby pomóc w pracy domowej - jakieś proste zdania, i powiedziałam, że ja już nie wiem. Czyli jaki z tego wniosek? To, że nie uczyłam się pilnie to fakt. Ale to nie powinno tak być, żebyśmy my musiały się uczyć w domu pilnie, bo wiadomo, że nie mamy czasu. Natomiast na zajęciach były głównie ćwiczenia, gramatyka, gramatyka, w domu też ćwiczenia gramatyczne, czasami też miałyśmy coś samodzielnie tworzyć, ale rzadko. Natomiast za mało było słuchania, mówienia, jak pojechałam do Hiszpanii - załamanie. Wiedziałam, że tak jest, ale nie było możliwości bezpośredniej konfrontacji. Ja, owszem potrafię zdanie sklecić. Wypowiedź ułożę, bo trochę słów znam, praktycznie myślę, że prawie wszystko mogę powiedzieć takim prostym angielskim, napisać. Natomiast, gdy nie rozumiem, co do mnie mówią. Po przyjeździe natychmiast panu o tym mówiłam, choć wcześniej już sygnalizowałam. Były takie sytuacje, kiedy przychodziłam, mówiłam „Good afternoon", a pan odpowiadał po polsku. Na początku trochę mówił do nas po angielsku, ale szybko przechodził do tłumaczenia gramatyki. Według mnie nie ma umiejętności pedagogicznych, tego czegoś ważnego dla nauczyciela. Jeżeli ja się cofnęłam w rozwoju, to przypuszczam, ze koleżanki jeszcze bardziej. Same ćwiczenia. Poza tym pan robi dużo jakichś dygresji, jak wyjaśnia coś i tłumaczy to samo po dziesięć razy. Jak wróciłam z Hiszpanii, poprosiłam pana wprost, bo przedtem były bardziej delikatne sugestie, o to, żebyśmy może więcej słuchali, bo ja niewiele rozumiałam. I raz słuchaliśmy. Potem nie było sprzętu, potem pan przygotował sprzęt, ale koleżanki poprosiły, aby wszystko powtórzyć, bo też się pogubiły. I pan przez godzinę opowiadał po polsku o gramatyce. Ja po godzinie pojechałam na szkolenie jakiejś rady pedagogicznej, a on tak opowiadał do końca zajęć. Brakuje mi tutaj ćwiczeń aktywizujących, zwłaszcza na słuchanie. Ja wcześniej byłam na innych lekcjach, gdzie na każdej lekcji było chociaż trochę do słuchania. Bo nawet, gdy pan mówi do nas po angielsku cały czas, to jest to tylko nauczyciel i wiadomo, że on mówi inaczej.

Chodzi mi też o marnowanie czasu, bo ja nie mam za wiele czasu. Na lekcjach on zwykle mówi o gramatyce, podaje jakieś reguły, mnóstwo dygresji odchodząc w bok, wyjątków, które tak naprawdę nie są nam wcale potrzebne, tylko zaciemniaja. Tak mi się to wszystko wymieszało, że ostatnio na proste pytanie, nie wiedziałam co powiedzieć. Jest gorzej z jakasś pewnościa, gotowością, myślę, że wcześniej tak nie było. Często też jest tak, że pan zadanych prac nie sprawdza. Nie byłam na pisaniu biznes planu, ale takie ćwiczenia uważam za wartościowe, bo coś 
tworzymy samodzielnie. Natomiast odrabianie ćwiczeń, w kółko tych samych, na papierze, niekoniecznie. Brakuje ćwiczeń w mówieniu i słuchaniu, a nie ciagle wypełnianie luk, łączenie.

Proponowałam koleżankom, żebyśmy uczyły się same, na jakiś innym kursie, ale wtedy byłoby to poza praca i trzeba byłoby zapłacić. Nie podjęły tematu. Nieprawda, że nie było motywacji z mojej strony. Po prostu kiepskie zajęcia, bardzo lubię pana, nie wiem, czy on nie umie, czy nie zdaje sobie sprawy. Oczywiście najłatwiej krytykować, ale ja chodziłam grzecznie przez dwa lata. Najpierw sygnały delikatne, potem ataki wprost. Pretensje do siebie? Nie wiem. Nie mam oporów przed mówieniem, idę po to, żeby się uczyć, żałuję tylko, że nie mam możliwości mówienia. Na ten moment rezygnuję z kursu, bo nie widzę sensu. Ale obiecuję sobie, że kiedyś się nauczę.

Zaprezentowana postawa Teresy może uchodzić za dojrzała, ponieważ wie, co chce osiagnąć. Wie również, co jest jej potrzebne i dlatego rezygnuje z nieefektywnego dla niej, choć darmowego kursu. W jej wypowiedzi nie ma udowadniania sobie, czy jest w stanie opanować nowy język, czy nie. Ona wie, że potrafi, ale muszą być spełnione warunki odpowiadające jej wyobrażeniom o nauczaniu języka. Dwa lata wcześniej dopominała się o większą liczbę sprawdzianów, informowanie uczącego o postępach i trudnościach, często podkreślając swój niedobór czasu. Można założyć, że tak ambitna osoba ma tylko czas na naukę, która rzeczywiście doprowadzi do wymiernych efektów. Jeżeli tego nie otrzymuje, odrzuca postawę zaangażowania cechującą inne kursantki i przyjmuje postawę oporu rezygnuje z kursu - ponieważ inwestuje zbyt dużo. Rezygnacja Teresy jest jej samodzielną decyzja, spowodowana, nie jak u Joanny, własnymi zahamowaniami, ale świadomym przerwaniem nieskutecznego dla niej kursu. Interesujące jest to, że Teresa nie chce zaprzestać nauki angielskiego - jest gotowa płacić za lekcje odbywające się poza praca, o ile tylko okażą się efektywne. W jej przypadku nastąpiła ewolucja od nauczania do poznawania siebie i swoich preferencji uczenia się, a więc od nauczania do uczenia się. W takich sytuacjach nauczyciel powinien zrewidować swoją tradycyjnie pełnioną rolę na rzecz przyjęcia roli doradcy (advisor), konsultanta (counsellor), czy facylitatora (facilitator), odrzucając myślenie, że pozycja nauczyciela wystarczy, aby samodzielnie ustalać scenariusze lekcji dla uczniów dorosłych, ponieważ „tylko uczniowie moga wiedzieć jakie materiały - z jakiego źródła - są im naprawdę przydatne” (Little, 1991: 48).

\subsection{Wnioski końcowe}

Dwuletnia obserwacja konsultantek metodycznych uczestniczących w kursie języka angielskiego dla początkujących pozwala na sformułowanie poniższych wniosków, dotyczących przeszkód, jak również możliwych konsekwencji uczenia się języka obcego w przypadku osób w wieku około-emerytalnym.

- Czynnik wieku. Nie należy przeceniać różnicy pomiędzy uczeniem się języka obcego przez osoby po 50ce oraz osoby młodsze wiekiem. W ba- 
daniu pojawiły się stwierdzenia sugerujące powątpiewanie niektórych uczestniczek w skuteczność nauki języka obcego osób dojrzałych (np. Joanna: „w moim wieku”, Iwona: „ułomność wieku”, „ćwiczenie pamięci”), niemniej, po dwóch latach nauki, większość uczestniczek kursu (trzy z dwóch) przyznaje, że postęp językowy, jakkolwiek powolny, miał miejsce w ich przypadku, zaś Teresa rezygnuje nie z powodu własnej niemożności uczenia się języka, lecz na skutek braku satysfakcji z kursu.

- Niskie poczucie pewności siebie. Można przyjać, że rozpatrywane w literaturze przedmiotu związki pomiędzy obrazem siebie a sukcesem w nauce języka obcego wystapiły również w tym badaniu. Z powodu obciążeń psychicznych sprowadzających się do poczucia wstydu, kompromitacji, dyskomfortu, jedna uczestniczka badania wycofuje się z kursu. Można także przyjąć, że początkowa zgoda na ,gąszcz informacji”, nieużytecznych z punktu widzenia kursantek, oznaczały brak poczucia sprawstwa albo uczucie niekompetencji ze strony badanych (paradoksalnie doradzających innym nauczycielom), aby zabierać głos i dopominać się o własne wersje lekcji.

- Zalą̇ki nowej tożsamości. Okres dwóch lat umożliwiający lepsze poznanie się nauczyciela i uczennic oraz postęp językowy spowodował, że badane zaczynają mówić własnym głosem. Zmianie ulega perspektywa postrzegania reprezentowana przez uczących się dorosłych w odniesieniu do roli i powinności ucznia. W momencie, kiedy konsultantki sygnalizuja własne preferencje odnośnie modelu ich uczenia się i zarzucają rolę pasywnych słuchaczek gramatycznych wykładów, pojawia się szansa na ich podmiotowość i emancypację.

- Doświadczenie ṡyciowe. Uczenie się języka obcego może stać się indywidualnym doświadczeniem życiowym, związanym ściśle z biografią konkretnej osoby. Wówczas uzyskana wiedza przestaje być jedynie zbiorem gramatycznych reguł i podręcznikowych słówek, a staje się częścią tożsamości uczących się. Dowartościowanie siebie, wyzwolenie u siebie empatii czy uwierzenie, że w potrzebie uaktywniają się nieznane pokłady wiedzy i umiejętności to przykłady takich niewymiernych, a niezwykle cennych komponentów nowej tożsamości, odkrytych czy umocnionych u badanych przy okazji uczenia się języka obcego. Może to także oznaczać, że ludzie dorośli nie tyle uczą się nowych rzeczy, co pogłębiają wiedzę, przekonania i postawy już posiadane.

- Rola nauczyciela. Badanie ukazuje dobitnie, że działania nauczyciela języka obcego nie moga pozostać obojętne wobec indywidualnych celów uczących się. Brak eksponowania celów indywidualnych w nauczaniu języka obcego (w badaniu podano brak ćwiczeń aktywizujących, rozwijania słuchania ze zrozumieniem, nawiązywania do literatury), przedkładanie celów społecznych czy odpowiadających nauczycielowi (nauczanie gramatyki, podawanie zbyt wielu znaczeń nowo poznanego słowa) - 
jednym słowem, brak dopasowania treści do doświadczeń uczniów jest skazane na niepowodzenie. Nauczyciel opisywany w badaniu nie ułatwiał nabywania nowej wiedzy, a poprzez własny styl nauczania jeszcze bardziej ja komplikował.

\section{Podsumowanie}

Opracowanie miało na celu poznanie przekonań i konsekwencji uczenia się języka obcego pięciu osób w wieku trzecim reprezentujących zawodową grupę pracowników oświaty. Dwuletnia obserwacja umożliwiła otrzymanie interesującego obrazu badanych, lecz należy zaznaczyć, że jest to spojrzenie na problem uczenia się języka obcego z jednej perspektywy - uczących się. Taki zawężony obraz może powodować nasze poruszanie się wyłącznie w sferze tymczasowych rozstrzygnięć, bardziej pytań niż odpowiedzi dotyczących procesu uczenia się języka obcego przez nauczycieli konsultantów po 50ce. Dlatego dociekań badawczych domagają się, na przykład, poniższe kwestie:

1. Czy istnieje hierarchia istotności czynników indywidualnych charakterystycznych dla uczących się dorosłych? Które są ważniejsze od innych (np. kwestia wieku czy obciażenia psychiczne), a które najważniejsze?

2. Czy nowe tożsamości uczących się dorosłych, nabyte na skutek uczenia się języka obcego, są trwałe i przekładają się na inne sfery ich działań?

3. Czy istnieje zgoda, które wizje uczenia się języka obcego (uczących się czy nauczyciela) są ważniejsze dla efektów językowych osób dorosłych?

4. Czy nauczyciele prowadzący kursy dla dorosłych powinni próbować zmienić poglądy swoich uczniów, jeżeli sa przekonani o ich nieskuteczności i czy takie próby zmian są etyczne?

Wyniki odpowiednio ukierunkowanych i przeprowadzonych badań moga dostarczyć ważnych informacji na temat różnych czynników wpływających na skuteczność uczenia się języka obcego w wieku trzecim, jak również działań, które należy podejmować, aby otrzymywać pożądane w tym względzie skutki.

\section{BIBLIOGRAFIA}

Alanen, R. 2006. „A sociocultural approach to young language learners' beliefs about language learning". (w:) Kalaja, P. i Barcelos, A. M. F. (red). Beliefs about SLA: New Research Approaches. New York: Springer: 55-86.

Bailey, K. M. 1995. „Competitivenss and anxiety in adult second language learning: looking at and through the diary studies". (w:) Brown, H. D i Gonzo, S. (red). Readings on Second Lnaguage Acquisition. Upper Saddle River, NJ: Prentice Hall Regents.

Barcelos, A. M. F. 2006. „Teachers' and students' beliefs within a Deweyan framework: conflict and influence". (w:) Kalaja, P. i Barcelos, A. M. F. (red). Beliefs about SLA: New Research Approaches. New York: Springer: 171-200. 
Bellingham, L. 2005. „Is there language acquisition after 40? Older learners speak up”. (w:) Benson, P. i Nunan, D. (red). Learners' Stories. Cambridge: CUP: 56-68.

Bernat, E. i Gvozdenko, I. 2005. „Beliefs about language learning: Current knowledge, pedagogical implications and new research dimensions". TESL-EJ. 9(1). http://www-writing.berkeley.edu?TESL-EJ/ej33/al.html DW: 02.01.2011.

Block, D. 2007. Second Language Identities. London: Continuum.

Dufva, H. 2006. „Beliefs in dialogue: a Bakhtinian view”. (w:) Kalaja, P. i Barcelos, A. M. F. (red). Beliefs about SLA: New Research Approaches. New York: Springer: 131-152.

Eriksen, T. H. 2003. Tyrania chwili. Warszawa: PIW.

Ho, D. G. E. 2007. Classroom Talk. Bern: Peter Lang.

Horwitz, E. K. 1985. „Surveying student beliefs about language learning and teaching in the foreign language methods course". Foreign Language Annals. 18(4): 333-340.

Hosenfeld, C. 2006. „Evidence of emergent beliefs of a second language learner". (w:) Kalaja, P. i Barcelos, A. M. F. (red). Beliefs about SLA: New Research Approaches. New York: Springer: 37-54.

Kalaja, P., Menezes, V. i Barcelos, A. M. F. 2008. Narratives of Learning and Teaching EFL. Basingstoke: Palgrave Macmillan.

Knowles, M. 1975. Self-Directed Learning. A Guide for Learners and Teachers. New York: Englewood Cliffs.

Kramsch, C. 2006. „Metaphor and the subjective construction of beliefs”. (w:) Kalaja, P. i Barcelos, A. M. F. (red). Beliefs about SLA: New Research Approaches. New York: Springer: 109-128.

Lantolf, J. P. 2000. Sociocultural Theory and Second Language Learning. Oxford: OUP.

Lantolf, J. P. i Pavlenko, A. 2001. „(S)econd (L)anguage (A)activity theory: understanding second language learners as people”. (w:) Breen, M. P. (red). Learner Contributions to Language Learning. Harlow: Pearson: 141-158.

Larsen-Freeman, D. 2001. „Individual cognitive/affective learner contributions and differential success in second language acquisition”. (w:) Breen, M. P. (red). Learner Contributions to Language Learning. Harlow: Pearson: 12-24.

Little, D. 1991. Learner AutonomyI: Definitions, Issues and Problems. Dublin: Authentik.

Lortie, D. 1975. School Teacher. A Sociological Study. Chicago: University of Chicago Press.

Malewski, M. 2010. Od nauczania do uczenia sie. O paradygmatycznej zmianie w andragogice. Wrocław: Wydawnictwo Naukowe Dolnośląskiej Szkoły Wyższej.

Norton, B. 2010. „Language and Identity”. (w:) Horngerger, N. H. i McKay, S. L. (red). Sociolinguistics and Language Education. Bristol: Multilingual Matters: 349-369.

Oxford, R. 1999. „Anxiety and the language learner”. (w:) Arnold, J. (red). Affect in Language Learning. Cambridge: CUP. 
Singleton, D. i Ryan, L. 2004. Language Acquisition: The Age Factor. Clevedon: Multilingual Matters.

Shoaib, A. i Dornyei, Z. 2005. „Affect in lifelong learning: Exploring L2 motivation as a dynamic process". (w:) Benson, P. i Nunan, D. (red). Learners' Stories. Cambridge: CUP: 22-41.

Wilczyńska, W. i Michońska-Stadnik, A. 2010. Metodologia badań w glottodydaktyce. Kraków: AVALON. 